Review Article

\title{
Surgical management for inferior turbinate hypertrophy: a narrative review
}

\author{
Mano Leoni Divya*, Valli Rajasekaran, D. Y. Raj Prakash
}

\begin{abstract}
Department of Otorhinolaryngology, Shri Sathya Sai Medical College and Research Institute, Sri Balaji Vidyapeeth University, Kancheepuram, Tamil Nadu, India
\end{abstract}

Received: 26 January 2021

Revised: 23 March 2021

Accepted: 01 April 2021

\author{
*Correspondence: \\ Dr. Mano Leoni Divya, \\ E-mail: divyabasker@gmail.com
}

Copyright: (c) the author(s), publisher and licensee Medip Academy. This is an open-access article distributed under the terms of the Creative Commons Attribution Non-Commercial License, which permits unrestricted non-commercial use, distribution, and reproduction in any medium, provided the original work is properly cited.

\begin{abstract}
Inferior turbinate hypertrophy can lead to bothersome symptoms of the nose. Inferior turbinate reduction has to be treated surgically for cases, which are refractory to medical treatment. Plethora of surgical techniques have evolved over the recent years to surgically treat inferior turbinate hypertrophy. Yet, there remains a lack of consensus on optimal surgical technique or a cumulative study on the merits and demerits of the surgical procedures performed. The aim of the study was to review 26 articles from time period of January 2000 to January 2021 studied on surgical techniques of turbinate reduction. On reviewing the studies, it was noted that conventional turbinectomy techniques were not preferred by surgeons to avoid chances of severe complications and hence more studies on newer advanced techniques were noted. Among the newer techniques to find an adequate balance between nasal physiology and tissue preservation RFTVR is preferred and is the optimal technique owing to its minimal invasion, performance ease and reduced complications. Most recent studies represent the benefits of RFTVR.
\end{abstract}

Keywords: Inferior turbinate hypertrophy, Turbinate reduction techniques, Turbinoplasty, Turbinectomy

\section{INTRODUCTION}

Treatment modality for inferior turbinate hypertrophy refractory to medical treatment is surgical reduction. ${ }^{1}$ Various surgical techniques for turbinate reduction have been studied. Optimal treatment technique includes resection of adequate tissue to reduce bulk of the turbinate and preserve viable mucosa to maintain nasal physiology. ${ }^{2}$ As newer surgical techniques are being explored for their efficacy. There is a lack of systemic comparative study of various turbinate reduction modality and their outcome. Objective of this study was to systematically evaluate the various surgical technique for treating inferior turbinate hypertrophy.

Articles were reviewed on surgical reduction of inferior turbinate hypertrophy and their outcomes were analyzed. This allowed us to study the most effective surgical technique for inferior turbinate hypertrophy.

\section{METHODS}

Search was undertaken using pubmed search engine to find various studies on surgical reduction of inferior turbinate hypertrophy from the months of January 2000 to January 2021. 26 articles relevant to our review as well as following our exclusion and inclusion criteria were included on surgical treatment of inferior turbinate hypertrophy comparing the effectiveness of surgical techniques; evaluating the treatment outcome of mentioned surgical techniques. Articles that had compared outcomes of techniques with other surgical procedures; were published in languages apart from English and single case report on specific intervention. Specific purpose of the study was to study the most appropriate surgical technique by comparing the treatment outcomes and occurrence of complication. Each technique with their merits and demerits were studied. Study year conducted, 
corresponding author, follow up period of the study, size of study and major findings were noted and studied.

Evaluation tools for subjective and objective symptoms pre and post operatively varied widely among most studies. It included NOSE scoring to visual analogue scale. Rhinomanommetric evidence for airway resistance in evaluating objective improvement were noted.
The PubMed research yielded 34 results. 26 articles were found to meet the inclusion criteria. Articles included the following surgical treatments of inferior turbinate hypertrophy: total turbinectomy, partial turbinectomy, sub mucosal resection, laser surgery, cryotherapy, electro cautery, radiofrequency ablation, and turbinate out fracture.

Table 1: Mentioned studies.

\begin{tabular}{|c|c|c|c|c|}
\hline Author of the study & $\begin{array}{l}\text { Year of } \\
\text { study }\end{array}$ & $\begin{array}{l}\text { Sample size } \\
\text { of the study }\end{array}$ & $\begin{array}{l}\text { Follow up } \\
\text { period }\end{array}$ & Major findings and conclusions of the study \\
\hline Bozan et al & 2010 & 66 & 2 months & $\begin{array}{l}\text { Turbinoplasty and out fracture have been found } \\
\text { effective tissue volume reduction techniques. } \\
\text { Turbinoplasty results in more reduction of turbinate } \\
\text { volume as compared to out fracture or bipolar } \\
\text { cauterization. }\end{array}$ \\
\hline Turk et al & 2017 & 59 & 6 months & $\begin{array}{l}\text { An effective and safe treatment option is } \\
\text { radiofrequency for inferior turbinate hypertrophy } \\
\text { for patients diagnosed with allergic rhinitis and } \\
\text { non-allergic rhinitis. }\end{array}$ \\
\hline Ercan et al & 2014 & 60 & 2 months & $\begin{array}{l}\text { Turbinate volume significant reduction, } \\
\text { improvement in subjective nasal symptoms after } \\
\text { Sub mucosal resection were found superior to those } \\
\text { after RFTVR (radio frequency turbinate volume } \\
\text { reduction). }\end{array}$ \\
\hline Deenadayal et al & 2006 & 200 & 24 months & $\begin{array}{l}\text { Bleeding in first post-operative period was seen in } \\
\text { radio frequency reduction. No case of extended } \\
\text { necrosis or atrophy of the turbinate with the } \\
\text { formation of crusts and no nasal dryness and no } \\
\text { synechiae was noted. }\end{array}$ \\
\hline Corso et al & 2004 & 305 & 5 years & $\begin{array}{l}\text { RFTVR shows improvement in nasal obstruction } \\
\text { and mouth breathing, after } 36 \text { months there was } \\
\text { progressive increasing rate of recurrences that were } \\
\text { significantly higher in allergic as compared to non- } \\
\text { allergic ones. }\end{array}$ \\
\hline Olszewska et al & 2010 & 46 & 3 months & $\begin{array}{l}\text { Mucotomy with } \mathrm{CO} 2 \text { laser improved patency of the } \\
\text { nose after } 3 \text { months in } 38 \text { patients }(82 \%) \text {, who } \\
\text { complained of disorder of air flow. It was } \\
\text { objectively measured with the help of anterior } \\
\text { rhinomanometry. Goblet cells proportion decreased } \\
\text { significantly in the follow-up at } 3 \text { months. }\end{array}$ \\
\hline Akagun et al & 2016 & 40 & 3 months & $\begin{array}{l}\text { Time of mucociliary transport was prolonged in } 1 \mathrm{st} \\
\text { week postoperatively and first month postoperative } \\
\text { in microdebrider assisted turbinoplasty. }\end{array}$ \\
\hline Henawi et al & 2011 & 46 & 6 months & $\begin{array}{l}\text { Blood loss intra operatively as well as surgery time } \\
\text { was less in power microdebrider turbinoplasty in } \\
\text { comparison to sub mucosal resection. }\end{array}$ \\
\hline Siu et al & 2020 & 8 & 1 month & $\begin{array}{l}\text { Greater reduction seen in nasal airway resistance } \\
\text { after turbinectomy. Turbinoplasty resulted in intra- } \\
\text { nasal aerodynamics closer to normal physiology } \\
\text { prominent jet-like course of flow stream was } \\
\text { observed following turbinectomy. }\end{array}$ \\
\hline Kumar et al & 2019 & 60 & 6 months & $\begin{array}{l}\text { Study on endoscopic turbinoplasty reveals } \\
\text { enhancement in nose block as well as lessened post- } \\
\text { operative symptoms in immediate post-operative } \\
\text { time in comparison to partial inferior turbinectomy. }\end{array}$ \\
\hline
\end{tabular}




\begin{tabular}{|c|c|c|c|c|}
\hline Author of the study & $\begin{array}{l}\text { Year of } \\
\text { study }\end{array}$ & $\begin{array}{l}\text { Sample size } \\
\text { of the study }\end{array}$ & $\begin{array}{l}\text { Follow up } \\
\text { period }\end{array}$ & Major findings and conclusions of the study \\
\hline Casale et al & 2014 & 48 & 45 days & $\begin{array}{l}\text { RFTVR represents a comparatively safe, least } \\
\text { invasive, easily performed, time as well as cost } \\
\text { effective surgery, which may decrease symptoms } \\
\text { related to snoring. }\end{array}$ \\
\hline Marques et al & 2007 & 24 & 1 year & $\begin{array}{l}\text { Both techniques turbinectomy as well as } \\
\text { turbinoplasty were similar in terms of the assessed } \\
\text { parameters. }\end{array}$ \\
\hline Mehta et al & 2019 & 150 & 1 year & $\begin{array}{l}\text { Coblation turbinoplasty was found effective for } \\
\text { turbinate reduction and effective for long term. } \\
\text { Reflex ultra has the advantage of preservation of } \\
\text { mucosa as well as minimal morbidity, turbinator } \\
\text { has the advantage of immediate relief of nasal } \\
\text { symptoms. }\end{array}$ \\
\hline Unsal et al & 2017 & 27 & 4 months & $\begin{array}{l}\text { inferior turbinate ablation can lead to } \\
\text { increase in the mean cross-sectional area and } \\
\text { volume of the nose as well as forced } \\
\text { expiratory volume. These differences in pre and } \\
\text { post-ablation results were statistically significant. }\end{array}$ \\
\hline Assanasen et al & 2014 & 48 & 1 month & $\begin{array}{l}\text { The treatment of nasal obstruction in patients by } \\
\text { radiofrequency turbinate reduction significantly } \\
\text { improved nasal obstruction, nasal itching, sneezing, } \\
\text { rhinorrhea, and sense of smell as assessed }\end{array}$ \\
\hline Parida et al & 2009 & 45 & 6 months & $\begin{array}{l}\text { The efficacy of diode laser reduction of turbinate in } \\
\text { treatment of symptomatic hypertrophy had } \\
\text { improvement from } 1 \text { week postoperatively crusting } \\
\text { and pain were main postoperative complaints. }\end{array}$ \\
\hline Mahajan et al & 2011 & 60 & 2 months & $\begin{array}{l}\text { Both sub mucous resection and powered } \\
\text { turbinectomy (PT) are efficient for relief of nasal } \\
\text { obstruction that is related to ITH. } \\
\text { PT is found to be an effective procedure in relieving } \\
\text { nasal obstruction preservation of inferior turbinate } \\
\text { function. }\end{array}$ \\
\hline Roamano et al & 2015 & 205 & 3 months & $\begin{array}{l}\text { In partial inferior turbinoplasty, crusting was not } \\
\text { noticed post procedure. In partial inferior } \\
\text { turbinectomy, crusting was seen to be raised } \\
\text { significantly within } 7 \text { days post procedure and then } \\
\text { decreased considerably after. }\end{array}$ \\
\hline Vijayakumar et al & 2012 & 30 & 3 months & $\begin{array}{l}\text { KTP laser reduction gives good results for reducing } \\
\text { the symptoms of allergic rhinitis as well as can be } \\
\text { performed as a day care procedure, with minimal } \\
\text { complications. Nasal mucociliary clearance has } \\
\text { been known to temporarily impair in initial } \\
\text { postoperative period, it returned thereafter to } \\
\text { normal. }\end{array}$ \\
\hline Uttarkar et al & 2014 & 80 & 3 months & $\begin{array}{l}\text { Bipolar electrocautery is better, safe and effective } \\
\text { for significant nasal obstruction reduction with } \\
\text { major after effect as postoperative pain which can } \\
\text { be managed effectively with conservative } \\
\text { management. }\end{array}$ \\
\hline Kumar et al & 2016 & 30 & 6 months & $\begin{array}{l}\text { When surgery is indicated, radio frequency } \\
\text { turbinate volume reduction known to be the } \\
\text { preferred treatment in cases of nasal obstruction } \\
\text { secondary to hypertrophy. Radio frequency ablation } \\
\text { therapy is equally effective, but also associated with } \\
\text { slightly higher chances of adverse effects. }\end{array}$ \\
\hline
\end{tabular}

Continued. 


\begin{tabular}{|c|c|c|c|c|}
\hline Author of the study & $\begin{array}{l}\text { Year of } \\
\text { study }\end{array}$ & $\begin{array}{l}\text { Sample size } \\
\text { of the study }\end{array}$ & $\begin{array}{l}\text { Follow up } \\
\text { period }\end{array}$ & Major findings and conclusions of the study \\
\hline Dhulipalla et al & 2015 & 90 & 3 months & $\begin{array}{l}\text { Radiofrequency turbinate reduction is ideal when } \\
\text { compared to electrocautery and cryotherapy } \\
\text { because there is maintenance of nasal physiology } \\
\text { without damaging nasal mucosa or underlying } \\
\text { nerves. }\end{array}$ \\
\hline Subhashini et al & 2019 & 209 & 6 months & $\begin{array}{l}\text { In the present study, the KTP laser was found to } \\
\text { improve the NOSE score when compared to diode } \\
\text { laser and the difference was significant. }\end{array}$ \\
\hline Doreyawar et al & 2019 & 60 & 6 months & $\begin{array}{l}\text { Diode laser being as good as any other laser for } \\
\text { turbinate reduction is an effective choice for } \\
\text { deserving cases. Although not as cost-effective as } \\
\text { conventional methods. }\end{array}$ \\
\hline Lukka et al & 2018 & 50 & 6 months & $\begin{array}{l}\text { Both submucous diathermy and submucous } \\
\text { resection are effective for the improvement of } \\
\text { airway in turbinate hypertrophy with an added } \\
\text { advantage in submucous resection in early post- } \\
\text { operative period. Reduced postoperative bleeding } \\
\text { as well as pain makes submucous diathermy a more } \\
\text { attractive option overall. }\end{array}$ \\
\hline Talmon et al & 2000 & 357 & 6 years & $\begin{array}{l}\text { Surgeons hesitate to use it for fear of disruption of } \\
\text { physiological function. The results show clearly } \\
\text { that the vast majority of patients who underwent } \\
\text { this operation enjoy better outcome after the } \\
\text { operation. As for the safety of total inferior } \\
\text { turbinectomy, the major complication is bleeding. }\end{array}$ \\
\hline
\end{tabular}

\section{DISCUSSION}

\section{Total turbinectomy}

Total turbinectomy is the procedure of removal of complete turbinate tissue along with turbinate bone. Surgeons often avoid performing total turbinectomy in recent years attributing to the fear of complications due to removal of excess nasal mucosa. 2 out of 30 articles were identified that studied total turbinectomy. Siu et al on studying nasal aerodynamics following the surgical procedure found that nasal airway resistance was greatly reduced following total turbinectomy and this was due to a significantly less pressure gradient at the inferior turbinate head. ${ }^{11}$

This study brings out the significant benefit of total turbinectomy. Another study by Talmon et al found that the only major complication is bleeding and effective techniques to reduce bleeding can overcome this complication. $^{28}$ Both the above studies, reflect total turbinectomy as an effective procedure with complications that can be managed with effective techniques.

\section{Partial turbinectomy}

Partial turbinectomy refers to selective trimming of the inferior turbinate. Partial turbinectomy removes an anterior portion of full-thickness tissue at the head of the inferior turbinate in the region of the internal nasal valve. 4 studies were identified that contribute to literature on partial turbinectomy. Mahajan et al found that partial turbinectomy is known to be effective in relieving nasal obstruction as well as optimal volume reduction with sustained preservation of function of inferior turbinate, $90 \%$ improvement in nasal obstruction and $83.3 \%$ improvement in size of turbinate turbinate was found. ${ }^{19}$

Marques et al in his comparative study found that turbinoplasty was as equally effective as turbinectomy. ${ }^{14}$ Kumar et al suggests that partial turbinectomy has significant improvement in nasal symptoms and aural symptoms in patients with allergic rhinitis. ${ }^{12}$

Roamano et al found that in partial inferior turbinectomy, crusting had been raised significantly within a period of 7 days post-procedure and further lessened considerably. ${ }^{20}$ The above studies suggest that partial turbinectomy aims at optimal tissue reduction to enable normal physiological functioning. Symptomatic relief following surgery is significant.

\section{Turbinoplasty}

Two main methods are known to fall under turbinoplasty, out fracture method as well as submucous resection method.

\section{Turbinate outfracture}

Turbinoplasty and outfracture are known to be effective volume reduction techniques. However, turbinoplasty 
causes higher reduction of the lower turbinate volume than outfracture.

\section{Submucosal resection}

An incision is to be made at inferior turbinate head. A micro debrider as well as blunt dissectors are further utilized so as to eliminate some of the hypertrophied turbinate tissue. Subsequently, the mucosa is redraped and allowed to heal over smaller turbinate bone. 3 articles from our review were studied on submucosal resection.

Lukka et al found submucosal resection to be cost saving compared to debrider, coblator, laser or techniques like radiofrequency assisted turbinectomy in their study, and none of their patients in Endoscopic submucosal resection (ESMR) group had significant intraoperative or postoperative bleeding. ${ }^{27}$ Recurrence of nasal obstruction due to inferior turbinate hypertrophy was not seen in patients who underwent ESMR. Ercan et al found significant turbinate volume reduction and improvement in nasal obstruction symptoms. ${ }^{5}$ Mahajan et al reported complications such as dryness of nose in $26.7 \%$, adhesions in $3.3 \%$ and crusting in $17 \%$ of the patients. ${ }^{19}$

\section{Microdebrider removal}

One study of the selected articles found to study on microdebrider removal. Akugan et al found that the time of mucociliary transport was notably prolonged in the first postoperative week as well as first postoperative month in microdebrider turbinoplasty group. ${ }^{9}$ Intra-operative blood loss was minimal in the power microdebrider turbinoplasty.

\section{Electrocautery}

Uttarkar et al and Lukka et al studied electrocautery and found it to be effective in reducing nasal obstruction and turbinate size. ${ }^{2,27}$ Major complications encountered were post-operative pain. Post-operative pan was effectively managed by conservative treatment.

\section{Laser cautery}

Vijayakumar et al found that KTP laser used for turbinate reduction showed results in reducing symptoms of allergic rhinitis as well as can be performed as day care procedure, with minimal complications. ${ }^{21}$ Although nasal mucociliary clearance was found to be temporarily impaired in the first few weeks of postoperative period, it returned to normal thereafter. Olszewska_ et al found that by $\mathrm{CO} 2$ laser mucotomy nasal patency was improved after 3 months in $82 \%$ patients. $^{8}$ Doreyawar et al found that diode laser being as good as any other laser for turbinate reduction is an effective choice for deserving cases. ${ }^{26}$ Although not as cost-effective as conventional methods, better quality of life with laser definitely makes it an important tool to replace the era of cold knife in turbinate surgeries in the modern day world.

\section{Radiofrequency ablation}

Casale et al, Dhulipalla et al, Assanasen et al and Kumar et al have studied on radiofrequency ablation. ${ }^{13,17,23,24}$ Conclusions indicate towards radio frequency ablation being the most ideal treatment option owing to its minimal invasion and its ease of performing the surgical procedure. It most effectively maintains normal nasal physiology without much damage to underlying mucosa or vessels and nerves.

\section{CONCLUSION}

Eight surgical techniques were compared which included both advanced and conventional surgical reduction of inferior turbinate hypertrophy. More studies are found on newer techniques such as radiofrequency ablation and fewer studies on techniques such as turbinoplasty and electro cautery.

Among conventional procedures, total inferior turbinectomy led to complication such as empty nose syndrome owing to disruption of normal nasal physiology. Even though it showed significant reduction in mucosal tissue and decreased airway resistance. Owing to fear of severe complications, total turbinectomy fails to be the optimal inferior turbinate reduction technique.

Partial turbinectomy and turbinoplasty in comparison with total turbinectomy have been noted to have fewer complications and hence a preferred choice among cost effective techniques. Turbinoplasty yields better outcomes in comparison to turbinectomy.

Among turbinoplasty types, submucosal resection is found to have better symptomatic outcome than out fracture technique even though out fracturing shows more reduction in turbinate volume. Advanced techniques such as microdebrider sub mucosal resection, laser, electro cautery as well as RFTVR. The technique of choice preferred by most studies as optimal is RFTVR. Complications such as intra operative bleeding seen in microdebrider or post-operative pain seen in electrocautery are not reported in studies of radiofrequency ablation.

As, conclusion surgically significant outcomes are best seen in turbinate reduction surgeries that are, minimally invasive, preserve adequate mucosal tissue, reduce airway resistance thereby relieving nasal symptoms and most importantly minimal complications. Most-newer and advance surgical techniques fit most of the above criteria. RFTVR emerges superior in terms of treatment and cost effectiveness.

\section{Funding: No funding sources Conflict of interest: None declared \\ Ethical approval: Not required}




\section{REFERENCES}

1. Dhulipalla S. Comparative study of response through reduction in the size of hypertrophied inferior turbinate causing nasal obstruction by different surgical modalities: a prospective study. Indian $\mathbf{J}$ Otolaryngol Head Neck Surg. 2015;67(1):56-9.

2. Oswal V, Krespi J, Kacker A. Nasal turbinate surgery. Principles and Practice of Lasers in Otorhinolaryngology and Head and Neck Surgery. USA: Kugler Publications; 2002: 221.

3. Bozan A, Eriş HN, Dizdar D, Gode S, Taşdelen B, Alpay HC. Effects of turbinoplasty versus outfracture and bipolar cautery on the compensatory inferior turbinate hypertrophy in septoplasty patients. Braz J Otorhinolaryngol. 2019;85(5):565-70.

4. Turk B, Korkut AY, Kaya KS, Salepçi E, Unsal O, Coşkun BU, et al. Results of Radiofrequency Ablation of Inferior Turbinate Hypertrophy in Patients with Allergic and Non-Allergic Rhinitis. Sisli Etfal Hastan Tip Bul. 2018;52(4):296-301.

5. Ercan C, Imre A, Pinar E, Erdogan N, Umut SE, Oncel S. Comparison of submucosal resection and radiofrequency turbinate volume reduction for inferior turbinate hypertrophy: evaluation by magnetic resonance imaging. Indian J Otolaryngol Head Neck Surg. 2014;66(3):281-6.

6. Deenadayal DS, Kumar MN, Sudhakshin P, Hameed $\mathrm{S}$. Radiofrequency reduction of inferior turbinates in allergic and non-allergic rhinitis. Indian $\mathrm{J}$ Otolaryngol Head Neck Surg. 2014;66(1):231-6.

7. Corso E, Bastanza G, Donfrancesco V, Guidi ML, Morelli SG, Passali GC, et al. Radiofrequency volumetric inferior turbinate reduction: long-term clinical results. Acta Otorhinolaryngol Ital. 2016;36(3):199-205.

8. Olszewska E, Sieskiewicz A, Kasacka I, Rogowski M, Zukowska M, Soroczyńska J, et al. Cytology of nasal mucosa, olfactometry and rhinomanometry in patients after $\mathrm{CO} 2$ laser mucotomy in inferior turbinate hypertrophy. Folia Histochem Cytobiol. 2010;48(2):217-21.

9. Akagun F, İmamoglu M, Çobanoglu HB, Ural A. Comparison of Radiofrequency Thermal Ablation and Microdebrider-Assisted Turbinoplasty in Inferior Turbinate Hypertrophy: A Prospective, Randomized, and Clinical Study. Turk Arch Otorhinolaryngol. 2016;54(3):118-23.

10. El HDD, Ahmed MR, Madian YT. Comparison between power-assisted turbinoplasty and submucosal resection in the treatment of inferior turbinate hypertrophy. ORL J Otorhinolaryngol Relat Spec. 2011;73(3):151-5.

11. Siu J, Inthavong K, Shang Y, Vahaji S, Douglas RG. Aerodynamic impact of total inferior turbinectomy versus inferior turbinoplasty - a computational fluid dynamics study. Rhinology. 2020;58(4):349-59.

12. Kumar KMP, Karthikeyan P, Nirmal CV. Comparison of Endoscopic Turbinoplasty Versus Conventional Partial Inferior Turbinectomy in
Chronic Hypertrophic Rhinitis. Indian J Otolaryngol Head Neck Surg. 2019;71(3):1895-99.

13. Casale M, Bottaro V, Sabatino L, Frari V, Bressi F, Vespasiani U, et al. The efficacy of radiofrequency volumetric tissue reduction of hypertrophied inferior turbinate in simple snoring. Eur Rev Med Pharmacol Sci. 2014;18(15):2160-8.

14. Rodrigues MM, Silveira DR, Francisco DOL, Dirce M, Marques O, Fernas M, et al. Comparison between turbinoplasty andendoscopic turbinectomy: Efficacy andclinical parameters. Int Arch Otorhinolaryngol. 2011;15(4):426-30.

15. Mehta N, Mehta S, Mehta N. Coblation-Assisted Turbinoplasty: A Comparative Analysis of Reflex Ultra and Turbinator Wand. Ear Nose Throat J. 2019;98(6):51-7.

16. Unsal O, Ozkahraman M, Ozkarafakili MA, Akpinar M, Korkut AY, Kurt DS, et al. Does the reduction of inferior turbinate affect lower airway functions?. Braz J Otorhinolaryngol. 2019;85(1):43-9.

17. Assanasen P, Choochurn P, Banhiran W, Bunnag C. Radiofrequency inferior turbinate reduction improves smell ability of patients with chronic rhinitis and inferior turbinate hypertrophy. Allergy Rhinol (Providence). 2014;5(1):12-6.

18. Parida PK, Surianarayanan G, Alexander A, Saxena SK, Santhosh K. Diode laser turbinate reduction in the treatment of symptomatic inferior turbinate hypertrophy. Indian J Otolaryngol Head Neck Surg. 2013;65(2):350-5.

19. Mahajan R, Nagaraj TM, Prashanth V. A Prospective Study to Compare the Efficacy of Powered Turbinectomy Versus Submucous Resection in the Surgical Management of Inferior Turbinate Hypertrophy. Indian J Otolaryngol Head Neck Surg. 2019;71(3):2203-9.

20. Romano A, Orabona GD, Salzano G, Abbate V, Iaconetta G, Califano L. Comparative study between partial inferior turbinotomy and microdebriderassisted inferior turbinoplasty. J Craniofac Surg. 2015;26(3):235-8.

21. Vijayakumar S, Divakaran S, Parida PK, Gopalakrishnan S. Potassium titanyl phosphate laser turbinate reduction in the management of allergic inferior turbinate hypertrophy: Our experience. Allergy Rhinol (Providence). 2016;7(1):29-33.

22. Rao SUP, Basavaraj P, Yempalle SB, Ramachandra AD. A Prospective Study of Different Methods of Inferior Turbinate Reduction. J Clin Diagn Res. 2017;11(5):1-3.

23. Kumar S, Anand TS, Pal I. Radiofrequency turbinate volume reduction vs. radiofrequency-assisted turbinectomy for nasal obstruction caused by inferior turbinate hypertrophy. Ear Nose Throat J. 2017;96(2):23-6.

24. Dhulipalla S. Comparative study of response through reduction in the size of hypertrophied inferior turbinate causing nasal obstruction by different surgical modalities: a prospective study. Indian J Otolaryngol Head Neck Surg. 2015;67(1):56-9. 
25. Ravichandran SP, Ramasamy K, Parida PK, Alexander A, Ganesan S, Saxena SK. Comparison of efficacy of potassium titanyl phosphate laser \& diode laser in the management of inferior turbinate hypertrophy: A randomized controlled trial. Indian J Med Res. 2020;151(6):578-84.

26. Doreyawar V, Gadag RP, Das M, Javali SB, Maradi N, Shetty D. Inferior Turbinate Reduction: Diode LASER or Conventional Partial Turbinectomy? Ear Nose Throat J. 2019;7:95.

27. Lukka VK, Kurien R, Varghese L, Rupa V. Endoscopic Submucosal Resection Versus Endoscopic Submucosal Diathermy for Inferior
Turbinate Hypertrophy. Indian J Otolaryngol Head Neck Surg. 2019;71(3):1885-94.

28. Talmon Y, Samet A, Gilbey P. Total inferior turbinectomy: operative results and technique. Ann Otol Rhinol Laryngol. 2000;109(12):1117-9.

Cite this article as: Divya ML, Rajasekaran V, Prakash DYR. Surgical management for inferior turbinate hypertrophy: a narrative review. Int J Otorhinolaryngol Head Neck Surg 2021;7:1076-82. 